\title{
Analisis Pola Kalimat Pada Rubrik Olahraga Kompas.com Bulan Maret 2021
}

\author{
Anissa Agustina \\ Prodi Pendidikan Bahasa dan Sastra Indonesia, Fakultas Bahasa dan Seni, Universitas Negeri \\ Semarang \\ anissaagustina49@gmail.com \\ Ayu Mutia \\ Prodi Pendidikan Bahasa dan Sastra Indonesia, Fakultas Bahasa dan Seni, Universitas Negeri \\ Semarang \\ ayumutia481@gmail.com \\ Fatimah Khusna \\ Prodi Pendidikan Bahasa dan Sastra Indonesia, Fakultas Bahasa dan Seni, Universitas Negeri \\ Semarang \\ fatimahkhusna123@gmail.com \\ Nazilatul Ikrimah \\ Prodi Pendidikan Bahasa dan Sastra Indonesia, Fakultas Bahasa dan Seni, Universitas Negeri \\ Semarang \\ nazilatulikrimah@gmail.com \\ Asep Purwo Yudi Utomo \\ Prodi Pendidikan Bahasa dan Sastra Indonesia, Fakultas Bahasa dan Seni, Universitas Negeri \\ Semarang \\ aseppyu@mail.unnes.ac.id
}

\begin{abstract}
ABSTRAK
Penelitian yang berjudul Analisis Pola Kalimat pada Rubrik Olahraga Kompas.com Bulan Maret 2021 bertujuan mendeskripsikan struktur sintaksis dan pola kalimat yang terdapat pada rubrik olahraga yang disajikan dalam berita online kompas.com edisi Maret 2021. Kajian yang dilihat dari struktur sintaksis adalah pola kalimat berdasarkan kategori, fungsi, dan peran sintaksis. Tujuan dari penelitian ini yaitu untuk mendeskripsikan struktur sintaksis dan menganalisis pola kalimat dasar Bahasa Indonesia. Analisis ini memakai metode kualitatif dan data sekunder seperti buku atau referensi. Dalam menganalisis data, peneliti menggunakan metode pengumpulan data simak yang diterapkan melalui teknik baca dan catat, serta menganalisis dengan menggunakan metode Agih. Terdapat beberapa tahapan dalam analisis pola kalimat ini yaitu tahapan membaca berita online, pencatatan pada data yang sesuai teori, mengidentifikasi, menganalisis, merumuskan, dan menyajikan data. Peneliti menganalisis delapan berita olahraga online pada kompas.com edisi Maret 2021. Analisis data penelitian ini menunjukkan struktur sintaksis pada kumpulan berita olahraga kompas.com yang meliputi pola kalimat berdasarkan fungsi, kategori, dan peran sintaksis.

Kata Kunci: Sintaksis, Pola Kalimat, Teks Berita Online, Rubrik Olahraga
\end{abstract}

\begin{abstract}
ABSTRAK
The study entitled "Analysis of Sentence Patterns in sports rubrics Kompas.com March 2021" aims to describe the syntax structure and sentence patterns contained in the sports rubric presented in the online news kompas.com the March 2021 issue. The study seen from the syntactic structure is a pattern of sentences based on categories, functions, and syntax roles. The purpose of this study is to describe the syntax structure and analyze the basic sentence patterns of Bahasa Indonesia. This analysis uses qualitative methods and secondary data such as books or references. In analyzing the data, researchers used a method of data collection that was applied through reading and recording techniques, as well as analyzing using the Agih method. There are several stages in the analysis of this sentence pattern, namely the stages of reading online news, recording on data that matches theory, identifying, analyzing, formulating, and presenting data. Researchers analyzed eight online sports news in kompas.com the
\end{abstract}


March 2021 issue. This analysis of research data shows the syntactic structure of the kompas.com sports news set which includes sentence patterns based on functions, categories, and syntax roles.

Keywords: Syntax, Sentence Patterns, Online News Text, Sports Rubrics

\section{PENDAHULUAN}

Bahasa mempunyai kontribusi besar dalam aktivitas keseharian manusia. Melalui bahasa, manusia dapat saling berkomunikasi dan bertukar pemikiran. Tidak hanya komunikasi secara lisan, melainkan dalam bentuk tulisan. Seorang penulis ataupun pengarang dapat membagikan pemikirannya kepada pembaca melalui bahasa yang ia tulis. Sebuah komunikasi dapat berjalan dengan lancar apabila terdapat persamaan makna atau maksud yang disampaikan. Hal ini memperlihatkan bahwa keterampilan berbahasa menjadi kunci utama dalam proses komunikasi, khususnya keterampilan dalam menyusun kalimat untuk digunakan ketika berinteraksi.

Setiap bahasa mempunyai kekhasan masing-masing yang tentunya tidak dimiliki oleh bahasa lainnya (Haryanti et al., 2018, p. 591). Ciri khas yang dimaksud tentu ada kaitannya dengan bunyi bahasa, pembentukan kata, kalimat, dan yang lainnya. Bahasa mempunyai peranan penting untuk mengungkapkan kemauan atau perasaan dalam mengekspresikan keinginan melalui interaksi dengan orang lain atau lingkungan sosialnya (Hermawan, 2018, p. 330). Pemaknaan sebuah percakapan tidak saja dapat dimaknai dari ujaran-ujaran yang disampaikan oleh peserta wicara tetapi pemaknaan juga ditentukan oleh strategi linguistik yang dipakai oleh masing-masing peserta wicara (Adnyana,2018:152) Hal ini memperlihatkan bahwa keberadaan bahasa dalam lingkup sosial tidak dapat begitu saja diabaikan. Melalui bahasa, beragam aspek sosial dapat diungkapkan oleh manusia ketika berinteraksi. Dalam ragam lisan maupun tulis, sudah sepatutnya untuk memperhatikan pilihan kata atau diksi yang digunakan sehingga dapat membentuk sebuah kalimat yang mudah diterima oleh lawan tutur ataupun pembaca (Septianingtias, 2015, p. 42).

Sejumlah kalimat sebagai bentuk bahasa tulis yang dihasilkan manusia hakikatnya dapat ditelusuri pola kalimatnya. Setiap kalimat pada masing-masing paragraf memerlukan pokok pikiran pada paragraf tersebut (Swarniti, 2021). Dalam pembahasan mengenai pola kalimat, tentunya tidak luput dari pembahasan mengenai ilmu sintaksis. Penyebutan sintaksis berasal dari ungkapan Belanda syntaxis dan bahasa Inggris syntax. Menurut Verhaar (2001, p. 11) sintaksis diartikan sebagai cabang ilmu bahasa yang menelaah urutan kata-kata pada suatu kalimat. Apabila 
pada morfologi menelaah struktur internal kata, sedangkan pada sintaksis menelaah struktur antar kata. Sedangkan menurut Kridalaksana (Kridalaksana, 2008) yang dijelaskan dalam Kamus Linguistik, 'sintaksis' bermakna pengaturan dan hubungan antara kata dengan kata, atau antara satuan kecil dengan satuan yang lebih besar. Berdasarkan kedua pendapat tersebut, dapat disimpulkan bahwa sintaksis merupakan ilmu yang cakupannya berisi tentang kalimat mulai dari satuan yang terkecil hingga yang lebih besar. Soeparno dalam (Rinanda, 2012, p. 14) menyatakan bahwa terdapat tiga tataran gramatikal sebagai kajian sintaksis, yaitu frasa, klausa, dan kalimat.

Salah satu kajian sintaksis adalah kalimat. Menurut Nirmalasari (2018, p. 43), kalimat adalah salah satu wujud produksi berbahasa. Kalimat diartikan sebagai satuan gramatikal yang dibatasi dengan adanya jeda panjang yang disertai nada akhir turun dan naik (Dewi, 2009, p. 29). Dalam hal ini, kalimat dapat berwujud lisan maupun tulisan. Menurut Tarigan (2009, p. 6), terdapat empat ciri utama kalimat, yaitu sebagai satuan bahasa, dapat berdiri sendiri secara relatif, mempunyai pola pada intonasi akhir, dan terdiri dari klausa. Menurut Mayasari (2017, p. 2), salah satu cara untuk menganalisis kalimat secara sintaksis dengan menggunakan fungsi, kategori, dan peran sintaksis sebagai komponen dari kalimat tersebut.

\section{Bentuk struktur kalimat berupa} susunan kata-kata yang dirangkai sesuai dengan aturan-aturan tata kalimat. Unsur yang berada di dalam kalimat harus menduduki posisi yang jelas dalam hubungan satu sama lain. Kalimat yang baik tentunya terdapat kesesuaian struktur atau pola kalimat. Berdasarkan hasil penelitian Mayasari dan Ardhana (2018, p. 60), struktur kalimat yang terdapat subjek dan predikat dapat dikategorikan sebagai kalimat tunggal yang gramatikal. Berbagai pola kalimat yang kita temui mempunyai kaidah kalimat baku yang dideskripsikan sesuai dengan pola kalimat dasar (Santika, 2018). Kalimat dasar memiliki informasi pokok dalam bentuk struktur inti dan belum terdapat perubahan ataupun penambahan.

Terdapat pula bentuk kalimat lainnya baik kalimat tunggal maupun majemuk yang berupa turunan dari kalimat dasar, dengan tetap menyesuaikan pola urutan unsur pembentukannya. Arifin (2008, p. 56) mengartikan kalimat tunggal sebagai bentuk kalimat yang hanya mempunyai satu subjek dan predikat. Kalimat yang tidak terdapat predikat ganda dapat dikategorikan ke dalam kalimat tunggal. Hal tersebut sesuai dengan pernyataan Yunregiarsih, Tarmini, dan Mustofa (2014, p. 6) dalam hasil penelitian 
mereka yang menyatakan bahwa sebuah kalimat dapat diklasifikasikan ke dalam jenis kalimat tunggal jika hanya memiliki satu predikat. Menurut Liusti (2016, p. 173), kalimat majemuk ditandai dengan adanya keberadaan konjungtor yang pada dasarnya merupakan cakupan dari beberapa klausa, dalam hal ini berupa kalimat tunggal (Santika, 2021). Sehingga dapat disimpulkan bahwa tata kalimat bahasa Indonesia dibedakan menjadi dua kelompok kalimat, yaitu kalimat dasar dan kalimat transformasi atau turunan dari kalimat dasar.

Dalam menyusun pola kalimat tentunya dibarengi dengan membangun gagasan pokok yang akan dituangkan dalam tulisan. Pola kalimat tidak hanya berdasarakan strukturnya saja tetapi juga berkaitan dengan konsep berpikir yang sesuai tata bahasa baku bahasa Indonesia (Suwarto, 2016, p. 5). Kalimat-kalimat yang saling memiliki kaitan antara satu dengan yang lain hingga membentuk kesatuan utuh yang disebut sebagai wacana. Wacana terbentuk dari beberapa kalimat yang saling berketerkaitan sehingga biasa dikatakan sebagai tingkatan tertinggi dalam hierarki kebahasaan. Wacana yang baik tentunya harus memperhatikan hubungan atar kalimatnya. Hubungan antar kalimat pada sebuah wacana tulis tersusun berkelanjutan dan membentuk kepaduan. Hal ini menjadi faktor penting dalam rangka meningkatkan keterbacaan (Widiatmoko, 2015, p. 2). Terdapat syarat membangun kalimat menjadi baik, meliputi ketepatan pemilihan diksi yang digunakan, kesesuaian diksi yang digunakan, penggunaan kata baku pada diksi (Utomo et al., 2019, p. 235).

Kebutuhan manusia mengenai informasi atau berita semakin hari semakin meningkat. Menurut Ariyadi dan Utomo (2020, p. 138) sebagian besar masyarakat mendapatkan informasi yang faktual, baik berupa kejadian atau pun peristiwa melalui membaca berita. Hal ini tentunya juga diikuti dengan adanya perkembangan teknologi informasi. Media masa merupakan salah satu sarana informasi yang memberi pengaruh besar terhadap pemahaman manusia tentang bahasa dan juga salah satu cara untuk memenuhi pembaruan dan pengembangan bahasa Indonesia yang baik (Nisa, 2018, p. 54). Dahulu manusia memperoleh informasi hanya melalui media cetak. Namun seiring perkembangan teknologi, sudah banyak bermunculan berita secara online. Masyarakat mulai memanfaatkan media online yang bersumber dari internet untuk mendapatkan informasi dengan lebih cepat. Salah satu informasi yang dapat diakses dengan mudah melalui internet yaitu berita atau surat kabar. Berita atau surat kabar dapat diartikan sebagai laporan tentang suatu kejadian atau peristiwa yang masih hangat dibicarakan 
(Widiatmoko, 2015). Berita dapat disampaikan secara lisan dan tulisan. Salah satu situs berita online yang dikenal oleh masyarakat Indonesia adalah kompas.com.

Kompas.com adalah salah satu media massa berita online di Indonesia yang bertujuan untuk memberikan layanan informasi atau berita terupdate dan aktual kepada para pembaca. Situs berita online ini cukup diminati oleh masyarakat terutama masyarakat Indonesia. Dalam kompas.com ini terdapat berbagai rubrik, mulai dari rubrik global, nasional, olahraga, edukasi, makanan, kesehatan, gaya hidup, ilmu pengetahuan, dan masih banyak lagi. Penulis telah melakukan obserbasi terhadap situs berita online kompas.com dan menemukan variasi pola kalimat yang digunakan dalam penulisan berita. Penerapan jenis kalimat pada surat kabar mempunyai berbagai variasi kalimat seperti kalimat tunggal, kalimat majemuk dan kalimat setara (Wahyuni et al., 2019, p. 660). Pemilihan bahasa yang tepat dalam berita menggambarkan kapasitas kebahasaan dalam pilihan kata dan kompleksitas tiap kalimat yang tertulis dalam pemberitaan tersebut. Penguasaan beragam unsur kebahasaan dan unsur di luar kebahasaan itu sendiri harus dikuasai oleh jurnalis atau seorang penulis berita, sehingga berita yang dihasilkan runtut, padu, kohesif, dan koheren (Goziyah \& Insani, 2018, p. 143).
Rubrik-rubrik olahraga dalam surat kabar harian atau majalah dianggap memiliki kontribusi yang besar terhadap olahraga dan menjadi topik yang cukup banyak disukai masyarakat (Haryati et al., 2017, p. 38). Melalui pemberitaan dalam rubrik khusus olahraga, pembaca dapat melihat dan menganalisis isi karya jurnalisistik yang khusus memberitakan tentang olahraga. Rubrik olahraga dipilih oleh penulis karena rubrik ini berisi informasi terkini yang berhubungan dengan olahraga yang tentunya diminati oleh pembaca yang ingin mengetahui informasi terbaru dan aktual tiap minggunya. Rubrik olahraga dalam berita harian kompas.com pada edisi Maret 2021 juga menjadi pembicaraan yang hangat akhir-akhir ini.

Dalam penulisan berita, bahasa tentunya menjadi unsur penting dalam hal mengkomunikasikan suatu berita kepada masyarakat atau pembaca (Mughofiroh et al., 2019, p. 160). Bahasa pada berita seringkali menggunakan bahasa yang berbeda dengan yang biasa digunakan dalam keseharian (Faraba et al., 2017, p. 44). Penulis berita menggunakan bahasa jurnalistik, di mana bahasa tersebut terkesan lebih padat, jelas, dan langsung masuk ke inti berita yang ingin disampaikan oleh penulis. Oleh karena itu dalam penulisan surat kabar, penting bagi seorang jurnalis atau penulis berita untuk memperhatikan 
aspek kebahasaan terutama pola kalimat pada berita yang ia tulis. Para jurnalis cenderung tidak memperhatikan hal tersebut, tetapi hanya fokus pada keaktualan berita dan informasi saja. Padahal aspek kebahasaan memiliki peran penting dalam suatu wacana berita (Santika, 2017). Di mana para pembaca akan lebih mudah dalam menafsirkan isi berita jika terdapat kepaduan bentuk maupun makna sesuai dengan aspek kebahasaannya. Ketidakpaduan aspek kebahasaan dalam suatu berita dapat membuat pembaca kesulitan dalam memahami isi berita. Masalah inilah yang melatarbelakangi peneliti untuk melakukan analisis pola kalimat pada rubrik olahraga komas.com edisi Marer 2021. Berdasarkan latar belakang itulah, peneliti terdorong untuk menganalisis penulisan beberapa berita pada rubrik olahraga kompas.com. Adapun permasalahan yang mendasar dalam analisis pola kalimat ini, yaitu (1) bagaimana bentuk pola kalimat pada wacana berita rubrik olahraga kompas.com edisi Maret 2021, (2) apakah terdapat kesalahan dalam penyusunan kalimat pada wacana berita rubrik olahraga kompas.com edisi maret 2021.

Peneliti sebelumnya sudah banyak melakukan penelitian mengenai analisis pola kalimat. Seperti Rinanda (Rinanda, 2012) yang mengkaji pola kalimat dalam wacana iklan brosur provider Telkomsel,
Septianingtias (Septianingtias, 2015) yang melakukan kajian pola kalimat dalam kumpulan dongeng Gadis Korek Api karya H.C. Andersen, serta Suwarto (Suwarto, 2016) meneliti tentang pola atau struktur bahasa Indonesia dalam karangan siswa kelas VI SD Negeri 02 Nglegok. Berbeda dari beberapa penelitian tersebut, penelitian ini menganalisis pola kalimat teks berita online yang berfokus dalam segi kajian sintaksis.

\section{METODE PENELITIAN}

Penelitian ini termasuk ke dalam telaah kasus. Adapun data pada penelitian ini bersumber dari delapan teks berita online Kompas.com pada edisi Maret 2021, yang secara khusus mengangkat isu mengenai olahraga, di antaranya yaitu (1) "Ditahan Man United, Thomas Tuchel Ukir Sejarah Bersama Chelsea" (1 Maret 2021), (2) "Timnas U23 Indonesia vs Tira Persikabo, Shin Tae-yong Sebut Kekurangan Garuda Muda" (5 Maret 2021), (3) "PBVSI: Semua Medali dan Penghargaan Aprilia Manganang Tak Akan Dicabut" (11 Maret 2021), (4) "All England 2021, Apriyani: Tak Ada Laga yang Mudah, Semua Berat" (16 Maret 2021), (5) "PP Perbasi Ingin Menyukseskan FIBA Asia Cup dan Tembus 8 Besar Asia" (27 Maret 2021), (6) “13 Tahun Pensiun, Oscar De La Hoya Comeback ke Ring Tinju Juli 2021" (27 Maret 2021), (7) "Pecatur 
Terbaik Dunia dan Indonesia" (28 Maret 2021), (8) "Evaluasi dan Apresiasi PBSI Usai Indonesia Nirgelar di Orleans Masters" (30 Maret 2021). Dengan adanya sumber data yang terbatas ini, maka kajian ini termasuk dalam telaah kasus.

Pada kajian ini menggunakan metode pengumpulan data simak yang diterapkan melalui teknik baca dan catat (Sudaryanto, 2015, p. 133). Terdapat pula tahapan pengumpulan data dalam kajian ini, meliputi; (a) inventarisasi data, (b) identifikasi data, serta (c) klasifikasi data. Sedangkan metode yang digunakan dalam analisisnya, yaitu metode analisis agih (Sudaryanto, 2015). Metode agih merupakan metode kajian yang alat penentunya terdapat di dalam dan termasuk bagian dari bahasa atau teks yang dikaji. Adapun tahapan dalam proses kajian ini, yaitu (1) pengumpulan data dengan cara membaca dan mencatat teks berita olahraga di Kompas.com; (2) analisis data dengan menelaah, membahas, dan mendeskripsikan fungsi, kategori, dan peran sintaksisnya; dan (3) membuat kesimpulan. Ketiga teknik tersebut dilakukan sesuai urutan metodologis.

\section{HASIL DAN PEMBAHASAN}

Penelitian ini berfokus pada analisis struktur sintaksis pada pola kalimat dan distribusinya dalam Bahasa Indonesia. Struktur sintaksis yang dibahas di sini mencakup kategori, peran, fungsi, dan satuan sintaksis. Di sini peneliti akan menganalisis beberapa bentuk pola kalimat yang terdapat dalam delapan berita seputar olahraga yang telah kami pilih pada Kompas.com edisi Maret 2021. Berdasarkan beberapa sumber berita Kompas.com, kami hanya mengambil beberapa data sebagai sampel yang sesuai dengan pembahasan dalam penelitian kami. Berikut adalah beberapa data kalimat yang terdapat dalam berita seputar olahraga pada Kompas.com.

1) Apriyani yang berpasangan dengan Greysia Polii mengatakan bahwa persiapan mereka sudah bagus. (dalam berita: All England 2021, Apriyani: Tak Ada Laga yang Mudah, Seтua Berat)

Pada kalimat di atas yang menempati fungsi subjek (S) adalah frasa Apriyani Rahayu yang berpasangan dengan Greysia Polii, di mana Apriyani Rahayu sebagai subjek induk yang termasuk kategori nomina, dan berperan sebagai pelaku yang mana mendapatkan perluasan subjek. Predikat (P) diisi oleh kata menyatakan yang berkateogi verba, dan berperan sebagai tindakan. Objek (O) diisi oleh persiapan mereka sudah bagus sebagai frasa nomina. 


\begin{abstract}
Pengisi fungsi-fungsi yang berupa kategori sintaksis mempunyai peran-peran sintaksis. Kata Apriyani Rahayu dan Greysia Polii dalam contoh diatas berperan sebagai 'pelaku' atau 'agentif', kata menyatakan memiliki peran 'perbuatan atau 'aktif', dan frasa persiapan mereka memiliki peran 'sasaran'. Berdasarkan analisis tersebut, kalimat di atas sudah sesuai dengan kaidah sintaksis Bahasa Indonesia. Hal ini sesuai dengan pendapat Chaer dalam (Rejeki, 2015, p. 30) yang menyebutkan bahwa kalimat merupakan susunan kata-kata yang teratur dan mengandung pikiran yang lengkap.
\end{abstract}

2) Apriyani dan rekan duetnya, Greysia Polii, akan menghadapi Kilasu Ostermever/Franziska Volkmann (Jerman) pada babak pertama All England 2021. (dalam berita: All England 2021, Apriyani: Tak ada Laga yang Mudah. Semua Berat)

Subjek (S) pada kalimat di atas adalah Apriyani dan rekan duetnya yang berkategori frasa nomina. Predikat (P) pada kalimat tersebut adalah akan menghadapi yang berkategori verba aktif. Objek
(O) pada kalimat tersebut adalah Kilasu Ostermever/Franziska Volkmann (Jerman) yang berkategori nomina. Terdapat pula keterangan (Ket) pada kalimat tersebut adalah pada babak pertama All England 2021 yang berkategori frasa adverbial.

Pada kalimat tersebut juga terdapat konektor 'dan'. Frasa Greysia Polii dalam kalimat tersebut termasuk kata keterangan Aposisi sebab memberikan keterangan pada subjek rekan duetnya. Pada kalimat tersebut Frasa Apriyani dan rekan duetnya, dan frasa Greysia Polii berperan sebagai 'pelaku' atau 'agentif', akan menghadapi memiliki peran' perbuatan' atau 'aktif', Kilasu Ostermever/Franziska Volkmann (Jerman) memiliki peran 'sasaran', dan pada babak pertama All England 2021 memiliki peran 'waktu'. Berdasarkan analisis tersebut, kalimat di atas sudah sesuai dengan kaidah sintaksis Bahasa Indonesia.

3) Rasanya excited bisa main di All England lagi. (dalam berita: All England 2021, Apriyani: Tak ada laga yang mudah, semua berat)

Dalam kalimat tersebut, kata rasanya mengisi dua fungsi, yaitu 
sebagai predikat $(\mathrm{P})$ dan objek $(\mathrm{O})$, kata excited mengisi fungsi keterangan (Ket) dengan kategori adjektiva, frasa bisa main mengisi fungsi predikat $(\mathrm{P})$ dengan kategori verba, sedangkan frasa di All England lagi mengisi fungsi keterangan (Ket). Kata Rasanya dalam kalimat diatas memiliki peran 'pengalam', kata excited memiliki peran 'keadaan', laga demi laga memiliki peran 'sasaran', serta frasa di All England 2021 memiliki peran 'tempat'. Dalam kalimat diatas terdapat beberapa fungsi keterangan,yaitu dengan urutan $\mathrm{K}$ acara mendahului $\mathrm{K}$ tempat secara kuantitas jangkauan pemakaian diikuti oleh (Munariswati et al., 2017, p. 293) ket. waktu (jika diperlukan). Urutan fungsi keterangan tersebut disebabkan oleh keterangan acara mempunyai relasi kejadian yang dekat dengan verba atau predikat.

Dari analisis pola kalimat diatas dapat dikatakan bahwa kalimat tersebut tidak sesuai dengan kaidah sintaksis. Dalam sintaksis terdapat syarat bagi sebuah kalimat, yaitu memiliki dua unsur wajib yaitu subjek dan predikat. Namun, dalam kalimat tersebut tidak terdapat adanya subjek sehingga kalimat tersebut dapat dikatakan sebagai kata yang tidak benar dan tidak sesuai dengan kaidah bahasa Indonesia.

4) Bagi Apriyani, tidak ada pertandingan mudah yang akan dilakoninya di ajang bulu tangkis tertua di dunia itu. (dalam berita: All England 2021, Apriyani: Tak ada laga yang mudah, seтиa berat)

Dalam kalimat tersebut, frasa bagi Apriyani mengisi fungsi sebagai subjek (S) yang berkategori nomina, tidak ada pertandingan mudah mengisi fungsi objek (O), frasa yang akan dilakoninya mengisi fungsi predikat $(\mathrm{P})$ dengan kategori verba, sedangkan frasa di ajang bulu tangkis tertua di dunia itu mengisi fungsi keterangan (Ket).

Kata Aptiyani dalam kalimat diatas memiliki peran 'pelaku', frasa tidak ada pertandingan mudah memiliki peran 'sasaran', yang akan dilakoninya memiliki peran 'perbuatan', serta frasa di ajang bulu tangkis tertua di dunia itu memiliki peran 'tempat'.

Dari analisis pola kalimat ini dapat dilihat bahwa penempatan urutan fungsi kategori dalam kalimat tersebut tidak sesuai dengan 
pola kalimat sintaksis. Hal tersebut disebabkan kalimat ini berpola S-OP-K. Umumnya subjek dan predikat terletak berurutan, tetapi dalam kalimat diatas letak antara subjek dan predikat disisipi oleh objek sehingga menyebabkan pola kalimat tersebut menjadi tidak padu.

5) Putri KW cs harus meningkatkan konsistensi sebab hal tersebut sangat dibutuhkan apabila bersua pemain papan atas. (dalam berita: Evaluasi dan Apresiasi PBSI Usai Indonesia Nirgelar di Orleans Masters)

Kalimat tersebut adalah kalimat majemuk bertingkat (subordinatif). Tarmini dan Sulistyawati (2019, p. 88) menjelaskan perbedaan antara kalimat majemuk bertingkat dan majemuk setara dapat dilihat dari hubungan antarklausa yang membentuknya. Penyebutan bertingkat digunakan untuk menunjukkan bahwa hubungan antarklausa sebagai pembentuk kalimat majemuk tidak dalam kedudukan yang sama.

Pada klausa 'Putri KW cs harus meningkatkan konsistensi' merupakan induk kalimat, sedangkan 'sebab hal tersebut sangat dibutuhkan apabila bersua pemain papan atas.' Merupakan anak kalimat. Anak kalimat dalam kalimat ini ditandai dengan konjungsi 'sebab'. Kata 'sebab' sebagai penanda anak kalimat berfungsi sebagai penegas bahwa anak kalimat merupakan sebab dari induk kalimat.

Pola kalimat pada induk kalimat antara lain: Putri $\mathrm{KW}$ cs mengisi fungsi subjek (S) yang berkategori nomina, harus meningkatkan mengisi predikat $(\mathrm{P})$ yang berkategori frasa verba, dan kata konsistensi mengisi fungsi objek (O) yang berperan sebagai nomina. Sedangkan pola kalimat pada anak kalimat, yaitu predikat (P) pada kata sangat dibutuhkan apabila bersua, objek (O) berada pada kata pemain, dan kata keterangan (Ket) berupa frasa papan atas.

Kata Putri KW cs dalam kalimat diatas memiliki peran 'pelaku', frasa harus meningkatkan dan dibutuhkan apabila bersua memiliki peran 'perbuatan', yang akan dilakoninya memiliki peran 'perbuatan', serta kata konsistensi, pemain, dan papan atas memiliki peran 'sasaran. Berdasarkan analisis 
tersebut, pola kalimat di atas sudah sesuai dengan kaidah sintaksis dalam Bahasa Indonesia.

6) Para pemain ini kan sudah lama tidak bertanding dan kemarin mereka menunjukkan semangat yang bagus. (dalam berita: Evaluasi dan Apresiasi PBSI Usai Indonesia Nirgelar di Orleans Masters)

Dalam kalimat frasa para pemain ini mengisi fungsi subjek $(\mathrm{S})$ yang berkategori nomina, sudah lama mengisi fungsi sebagai keterangan (Ket), kata bertanding mengisi fungsi predikat $(\mathrm{P})$ pertama yang berkategori verba, kemarin mengisi fungsi keterangan (Ket) ke2, mereka mengisi fungsi subjek (S) ke-2, menunjukkan mengisi predikat (P) ke-2, semangat mengisi fungsi objek (O) yang berkategori nomina, dan frasa yang bagus mengisi fungsi keterangan (Ket) ke-3 sebagai atribut yang berkategori adjektiva.

Frasa para pemain ini dan mereka memiliki peran 'pelaku', bertanding dan menunjukkan memiliki peran 'perbuatan', semangat memiliki peran 'penderita', sudah lama dan kemarin memiliki peran 'waktu', serta frasa yang bagus memiliki peran 'cara'. Pada kalimat di atas menunjukkan adanya pola kalimat majemuk bertingkat. Berdasarkan analisis tersebut, pola kalimat di atas sudah sesuai dengan kaidah sintaksis dalam bahasa Indonesia.

7) PP Perbasi bertekad meraih kesuksesan dalam menggelar FIBA Asian Cup. (dalam berita: PP Perbasi Ingin Menyukseskan FIBA Asia Cup dan Tembus 8 Besar Asia) Dalam kalimat berita di atas, PP Perbasi sebagai subjek (S) dengan peran sebagai pelaku dan berkategori nomina. Bertekad meraih menjadi predikat $(\mathrm{P})$ dengan peran sebagai tindakan dan berkategori frasa verba. Kata kesuksesan berfungsi sebagai objek (O) yang berperan sebagai hasil dengan kategori nomina. Menggelar berfungsi sebagai predikat (P) kedua yang berperan sebagai Tindakan dengan kategori verba. FIBA Asian Cup sebagai objek (O) kedua yang berperan sebagai hasil dan berkategori nomina. Pada kalimat di atas menunjukkan adanya pola kalimat majemuk bertingkat. Berdasarkan analisis tersebut, pola kalimat di atas sudah sesuai dengan kaidah sintaksis dalam bahasa Indonesia. 
8) Untuk penyelenggaraan, Perbasi sudah melakukan koordinasi dengan semua stakeholder bola basket. (dalam berita: PBVSI: Semua Medali dan Penghargaan Aprilia Manganang Tak Akan Dicabut)

Untuk merupakan konjungsi subordinative tujuan. Penyelenggaraan merupakan keterangan (Ket). Perbasi menempati fungsi subjek (S) yang berperan sebagai pelaku dan berkategori nomina. Frasa sudah melakukan menempati fungsi predikat $(\mathrm{P})$ memiliki peran sebagai Tindakan dan berkategori frasa verba. Fungsi objek $(\mathrm{O})$ ditempati oleh koordinasi yang berperan sebagai hasil dan berkategori nomina. Kata dengan merupakan konjungsi koordinatif penjumlahan. Semua stakeholder bola basket menempati fungsi keterangan (Ket) kedua yang berperan sebagai keterangan penyerta dan berkategori frasa adverbial.

9) Menurut dia, semua medali yang telah diraih Aprilia tidak akan dicabut karena hal tersebut bukanlah kesengajaan. (dalam berita: PBVSI: Semua Medali dan
Penghargaan Aprilia Manganang Tak Akan Dicabut)

Kata menurut merupakan predikat $(\mathrm{P})$ dengan kategori verba dari subjek (S) dia yang berperan sebagai pelaku dan berkategori pronominal. Semua medali berfungsi sebagai subjek (S) dengan peran pelaku dan berkategori frasa nomina. Kata yang merupakan partikel. Telah diraih menduduki fungsi predikat $(\mathrm{P})$ dengan peran sebagai tindakan dan berkategori frasa verba. Kata Aprilia sebagai objek (O) yang berperan sebagai sasaran dan kategorinya sebagai nomina. Frasa akan dicabut merupakan predikat (P) dengan peran sebagai Tindakan yang berkategori frasa verba. Karena merupakan sebuah konjungsi. Frasa hal tersebut merupakan subjek (S) yang berperan sebagai pelaku, berkategori frasa nomina. Bukanlah termasuk predikat $(\mathrm{P})$ dengan afikslah yang berperan sebagai keadaan dan berkategori adverbial. Kesengajaan merupakan objek (O) yang berperan sebagai sasaran dan berkategori nomina.

10) Sehingga kita tak akan mencabut dan itu tetap akan menjadi hak April. (dalam berita: PBVSI: Semua 
Medali dan Penghargaan Aprilia Manganang Tak Akan Dicabut)

Sehingga merupakan konjungsi subordinative pengakibatan. Kata kita sebagai subjek (S) berperan sebagai pelaku dan berkategori nomina. Frasa akan mencabut berfungsi sebagia predikat (P) yang berperan sebagai Tindakan dan berkategori frasa verba. Kata dan merupakan konjungsi. Itu merupakan subjek (S) yang berperan sebagai penanggap dan berkategori pronominal. Tetap menjadi keterangan (Ket). Frasa akan menjadi sebagai predikat $(\mathrm{P})$ dengan peran sebagai Tindakan dan berkategori frasa verba. Hak April menempati fungsi objek (O) dengan peran sebagai sasaran dan berkategori frasa nomina. Pada kalimat di atas menunjukkan adanya pola kalimat majemuk bertingkat. Berdasarkan analisis tersebut, pola kalimat di atas sudah sesuai dengan kaidah sintaksis dalam bahasa Indonesia.

11) Thomas Tuchel berhasil mengukir sejarah Bersama Chelsea seusai laga melawan Manchester United pada laga pekan ke-26 Liga Inggris 2020-2021. (dalam berita: Ditahan
Man United, Thomas Tuchel Ukir Sejarah Bersama Chelsea)

Pada kalimat di atas, yang menempati fungsi subjek (S) adalah Tomas Tuchel yang berkatagori nomina yang berperan sebagai pelaku, sedangkan predikat $(\mathrm{P})$ diisi oleh berhasil mengukir memiliki peran sebagai tindakan, objek (O) dalam kalimat tersebut adalah sejarah berperan sebagai sasaran dan berkategori frasa, Bersama Chealse adalah keterangan tempat berkategori frasa, dan seusai laga melawan Manchester United pada laga pekan ke-26 Liga Inggris 20202021 berperan sebagai keterangan waktu berperan sebagai peluasan waktu.

12) Chelsea bermain imbang saat bersua Man United di Stadion Stamford Bridge pada minggu 28 februari 2021 malam. (dalam berita: Ditahan Man United, Thomas Tuchel Ukir Sejarah Bersama Chelsea)

Fungsi dan peran sintaksis yang terkandung pada kalimat tersebut, yaitu Subjek (S) pada kalimat diatas adalah Chelsea berkatagori nomina dan memiliki peran sebagai pelaku. Predikat (P) diisi dengan kata bermain yang 
berkategori verba dan berperan sebagai tindakan. Pelengkap (Pel) diisi oleh kata imbang yang berperan sebagai sasaran tindakan. Keterangan (Ket) diisi oleh frasa saat bersua Man United di Stadion Stamford Bridge pada minggu 28 februari 2021 malam sebagai keterangan waktu dan berperan sebagai peluasan waktu.

13) Thomas Tuchel menjadi pelatih Chelsea pertama yang tidak kebobolan satu gol pun dalam empat partai kendang pertamanya di Liga Inggris. (dalam berita: Ditahan Man United, Thomas Tuchel Ukir Sejarah Bersama Chelsea)

Pada kalimat tersebut, fungsi subjek (S) adalah Thomas Tuchel berkategori nomina dan memiliki peran sebagai pelaku. Predikat $(\mathrm{P})$ diisi oleh kata menjadi yang berkategori verba dan memiliki peran sebagai tindakan, ada pun klausa pelatih Chelsea pertama yang tidak kebobolan satu gol pun yang merupakan peluasan predikat, dalam empat partai kendang pertamanya sebagai keterangan waktu (Ket), di Liga Inggris sebagai keterangan tempat berkategori frasa adverbial.
14) Rafli menceploskan bola ke gawang Laskar Padjadjaran dengan kepalanya usai memanfaatkan umpan silang Kushedya Hari Yudo. (dalam berita: Timnas U23 Indonesia vs Tira Persikabo, Shin Tae-yong Sebut Kekurangan Garuda Muda)

Pada kalimat tersebut, kata Rafli menempati fungsi sebagai subjek (S) yang termasuk dalam kategori nomina dan berperan sebagai pelaku. Predikat (P) diisi oleh kata menceploskan yang berkategori verba dan berperan sebagai tindakan. Kata bola berfungsi sebagai objek (O) yang berkategori nomina dan berperan sebagai sasaran. Dalam kalimat di atas, frasa ke gawang Laskar Padjadjaran berfungsi sebagai keterangan (Ket) yang berkategori frasa adverbial dan berperan sebagai keterangan tempat. Selanjutnya pada frasa dengan kepalanya juga memiliki fungsi sebagai keterangan (Ket) yang berperan sebagai keterangan cara dan berkategori frasa adverbial. Ada pula fungsi keterangan (Ket) yang lainnya yang ditunjukkan pada kata usai memanfaatkan umpan silang Kushedya Hari Yudo yang 
berkategori frasa adverbial dan berperan sebagai perluasan waktu.

15) Bagi banyak orang, dia adalah yang terbaik yang pernah memainkan permainan asah otak, meskipun GM Garry Kasparov dan Bobby Fischer tetap menjadi pembicaraan. (dalam berita: Pecatur Terbaik Dunia dan Indonesia)

Pada kalimat di atas dapat dianalisis pola kalimatnya sesuai fungsi, kategori, dan peran sintaksisnya, yakni pada kata bagi banyak orang memiliki fungsi keterangan (K) yang berperan sebagai keterangan penyerta dan berkategori klausa. Kata dia memiliki fungsi subjek (S) yang berperan sebagai pelaku, dan berkategori pronominal. Frasa adalah yang terbaik yang pernah memainkan mengisi fungsi predikat (P) yang berperan sebagai tindakan dan memenuhi kriteria sebagai klausa verba, sebab mempunyai frasa yang berkategori verba (golongan kata kerja) sebagai pangkal atau dasarnya (Aditia \& Utomo, 2021, p. 12). Kata permainan asah otak memiliki fungsi objek (O) yang memiliki peran yaitu sasaran, dan berkategori nomina. Kata meskipun memiliki fungsi konjungsi (konj), berkategori partikel, dan memiliki peran kata hubung. Selanjutnya terdapat kata GM Garry Kasparov dan Bobby Fischer yang memiliki fungsi subjek (S) yang berperan sebagai pelaku, dan berkategori nomina. Kata tetap menjadi berfungsi predikat $(\mathrm{P})$ yang memiliki peran tindakan, dan berkategori verba. Pada kata pembicaraan memiliki fungsi sebagai pelengkap (Pel) yang menempati peran sebagai sasaran dan termasuk dalam kategori nomina. Berdasarkan analisis tersebut, dapat diketahui bahwa pola kalimat di atas termasuk pola kalimat majemuk bertingkat.

16) GM Susanto Megaranto menduduki peringkat pertama pecatur dari Indonesia. (dalam berita: Pecatur Terbaik Dunia dan Indonesia)

Pada kalimat di atas dapat dianalisis pola kalimatnya sesuai fungsi, kategori, dan peran sintaksisnya, yakni fungsi subjek (S) ditempati oleh kata GM Susanto Megaranto yang berperan sebagai pelaku dan berkategori nomina. Fungsi predikat (P) ditempati oleh kata menduduki yang memiliki 
peran sebagai pelaku dan berkategori verba. Fungsi objek (O) ditempati oleh kata peringkat pertama pecatur yang memiliki peran sebagai sasaran dan berkategori frasa nominal. Adapula fungsi keterangan (Ket) diisi oleh kata dari Indonesia yang memiliki peran sebagai keterangan asal dan berkategori frasa adverbial.

17) Di urutan kedua peringkat catur Indonesia ditempati GM Novendra Priasmoro dengan memiliki ELO 2502. (dalam berita: Pecatur Terbaik Dunia dan Indonesia)

Pada kalimat di atas dapat dianalisis pola kalimatnya sesuai fungsi, kategori, dan peran sintaksisnya, yakni kata di urutan kedua peringkat catur Indonesia berfungsi keterangan (Ket.) yang memiliki peran sebagai keterangan tempat dan berkategori klausa. Kata ditempati berfungsi predikat $(\mathrm{P})$, berperan tindakan, berkategori verba. Kata GM Novendra Priasmoro berfungsi subjek (O) yang berperan sebagai pelaku dan berkategori nomina. Kata dengan memiliki ELO 2502 berfungsi sebagai keterangan (Ket.) yang berperan sebagai keterangan alat dan berkategori frasa adverbial.
Pada kalimat ini terdapat penggunaan kata di yang kurang tepat dalam klausa di urutan kedua peringkat catur Indonesia. Kata tersebut seharusnya dapat berfungsi sebagai objek (O) yang berperan sebagai penderita dan berkategori klausa. Namun, akibat penambahan kata di menyebabkan klausa tersebut berubah fungsi menjadi keterangan. Hal ini memperlihatkan bahwa bentuk pola kalimat tersebut kurang tepat. Adapula pendapat Surbakti (2012, p. 66) yang menjelaskan bahwa subjek kalimat pasif umumnya secara khas diperankan oleh suatu frasa nomina dan memiliki peran semantik sebagai penderita.

18) Adapun, Woman Grandmaster (WGM) Irene Kharisma Sukandar yang beberapa waktu lalu menjadi perbicangan setelah berhasil mengalahkan Dewa Kipas alias Dadang Subur. (dalam berita: Pecatur Terbaik Dunia dan Indonesia)

Pada kalimat di atas dapat dianalisis pola kalimatnya sesuai fungsi, kategori, dan peran sintaksisnya, yakni kata adapun memiliki fungsi konjungsi (konj) yang berperan sebagai kata hubung 
dan berkategori partikel. Fungsi subjek (S) pada kalimat ini ditempati kata Woman Grandmaster (WGM) Irene Kharisma Sukandar yang beberapa waktu lalu menjadi perbincangan yang berperan sebagai pelaku dan berkategori nomina dengan adanya perluasan subjek. Fungsi predikat $(\mathrm{P})$ diisi oleh frasa setelah berhasil mengalahkan yang berperan sebagai tindakan dan berkategori verba. Fungsi objek (O) ditempati kata Dewa Kipas yang memiliki peran sebagai sasaran dan berkategori nomina, adapula kata alias Dadang Subur berfungsi sebagai pelengkap (Pel) yang berperan sebagai sasaran dan berkategori nomina.

19) Dia menempati peringkat kelima pecatur terbaik Indonesia. (dalam berita: Pecatur Terbaik Dunia dan Indonesia)

Pada analisis pola kalimat ditemukan fungsi subjek (S) ditempati oleh kata dia yang menempati peran sebagai pelaku dan termasuk dalam kategori pronominal. Kata menempati memiliki fungsi predikat $(\mathrm{P})$ yang berperan sebagai tindakan dan termasuk dalam kategori verba. Pada fungsi objek (O) diisi oleh kata peringkat kelima yang memiliki peran sebagai sasaran dan termasuk dalam kategori frasa nominal. Adapula kata pecatur terbaik Indonesia memiliki fungsi keterangan (K) yang termasuk dalam kategori frasa adjektifal.

20) Legenda tinju Amerika Serikat, Oscar De La Hoya, memutuskan kembali ke ring pada 3 Juli 2021 setelah 13 tahun pensiun. (dalam berita: 13 Tahun Pensiun, Oscar De La Hoya Comeback ke Ring Tinju Juli 2021)

Pada kalimat di atas dapat dianalisis pola kalimatnya sesuai fungsi, kategori, dan peran sintaksisnya, yakni fungsi subjek (S) ditempati oleh kata legenda tinju Amerika Serikat, Oscar De La Hoya yang berperan sebagai pelaku dan termasuk dalam kategori nomina dengan perluasan subjek. Kata memutuskan berfungsi predikat $(\mathrm{P})$ yang berperan sebagai tindakan dan termasuk kategori verba. Kata kembali berfungsi pelengkap (Pel) yang memiliki peran sebagai sasaran dan termasuk dalam kategori nomina. Kata ke ring pada 3 Juli 2021 setelah 13 tahun pensiun berfungsi keterangan (K) yang memiliki peran sebagai keterangan 
tempat dan waktu dan termasuk dalam kategori frasa adverbial.

21) Setelah mengumumkan hal itu, Oscar De La Hoya langsung membanting mic dan meninggalkan ruangan konferensi pers. (dalam berita: 13 Tahun Pensiun, Oscar De La Hoya Comeback ke Ring Tinju Juli 2021)

Pada kalimat di atas dapat dianalisis pola kalimatnya sesuai fungsi, kategori, dan peran sintaksisnya, yaitu kata setelah mengumumkan hal itu memiliki fungsi keterangan (K) yang menempati peran perluasan keterangan waktu, dan termasuk kategori frasa adverbial. Fungsi subjek (S) diisi oleh kata Oscar De La Hoya yang memiliki peran sebagai pelaku dan termasuk dalam kategori nomina. Fungsi predikat (P) diisi oleh kata langsung membanting yang menempati peran sebagai tindakan dan termasuk dalam kategori verba. Kata mic memiliki fungsi objek (O) yang menempati peran sasaran dam termasuk dalam kategori nomina. Kata dan memiliki fungsi konjungsi (konj) yang menempati peran kata hubung kalimat majemuk setara dan termasuk dalam kategori partikel.
Kata meninggalkan memiliki fungsi predikat $(\mathrm{P})$ yang menempati peran tindakan dan termasuk dalam kategori verba. Kata ruangan konferensi pers memiliki fungsi objek $(\mathrm{O})$ yang menempati sasaran dan termasuk dalam kategori frasa nominal.

22) Malki Kawa mengaku sudah berbicara dengan pihak Oscar De La Hoya untuk menggelar duel ekshibisi pada April 2021. (dalam berita: 13 Tahun Pensiun, Oscar De La Hoya Comeback ke Ring Tinju Juli 2021)

Pada kalimat di atas dapat dianalisis pola kalimatnya sesuai fungsi, kategori, dan peran sintaksisnya, yaitu fungsi subjek (S) ditempati kata Malki Kawa yang memiliki peran pelaku dan termasuk dalam kategori nomina. Fungsi predikat $(\mathrm{P})$ ditempati kata mengaku yang memiliki peran sebagai tindakan dan termasuk dalam kategori verba. Fungsi keterangan (K) diisi oleh kata sudah berbicara dengan pihak Oscar De La Hoya untuk menggelar duel eskhibisi pada April 2021 yang memiliki peran sebagai keterangan penyerta, tujuan, dan waktu di mana berupa perluasan 
keterangan dan termasuk dalam kategori frasa adverbial.

23) Namun, Mali Kawa menyebut Oscar De La Hoya telah menolak tawaran tersebut. (dalam berita: 13 Tahun Pensiun, Oscar De La Hoya Comeback ke Ring Tinju Juli 2021)

Pada kalimat di atas dapat dianalisis pola kalimatnya sesuai fungsi, kategori, dan peran sintaksisnya, yakni kata namun berfungsi konjungsi (Konj) yang menempati peran dalam menghubungkan antar kalimat. Kata Mali Kawa berfungsi subjek (S) yang menempati peran sebagai pelaku dan termasuk dalam kategori nomina. Kata menyebut memiliki fungsi predikat (P) yang memiliki peran sebagai tindakan dan termasuk dalam kategori verba. Kata Oscar De La Hoya memiliki fungsi sebagai objek (O) yang menempati peran sebagai sasaran, dan termasuk dalam kategori nomina. Kata telah menolak tawaran tersebut memiliki fungsi keterangan (K) yang menempati peran keterangan penyerta dan termasuk dalam kategori frasa adverbial.

24) Empat bulan setelah menghadapi Pacquiao, Oscar De La Hoya memutuskan gantung sarung tinju alias pensiun. (dalam berita: 13 Tahun Pensiun, Oscar De La Hoya Comeback ke Ring Tinju Juli 2021)

Pada kalimat di atas dapat dianalisis pola kalimatnya sesuai fungsi, kategori, dan peran sintaksisnya, yaitu kata empat bulan setelah menghadapi Pacquiao memiliki fungsi keterangan (K) yang berperan sebagai perluasan keterangan waktu dan berkategori frasa adverbial. Fungsi subjek (S) ditempati kata Oscar De La Hoya yang memiliki peran sebagai pelaku dan termasuk dalam kategori nomina. Fungsi predikat $(\mathrm{P})$ diisi kata memutuskan berfungsi yang menempati peran sebagai tindakan dan termasuk dalam kategori verba. Adapula fungsi pelengkap (Pel) yang diisi oleh kata gantung sarung tinju alias pensiun yang memiliki peran sebagai sasaran dan termasuk dalam kategori frasa nominal.

25) Oscar De La Hoya kini melanjutkan karier sebagai promotor tinju di bawah naungan Golden Boy Promotions. (dalam berita: 13 Tahun Pensiun, Oscar De La Hoya Comeback ke Ring Tinju Juli 2021)

Pada kalimat di atas dapat dianalisis pola kalimatnya sesuai 
fungsi, kategori, dan peran sintaksisnya, yaitu fungsi subjek (S) diisi kata Oscar De La Hoya yang menempati peran sebagai pelaku dan termasuk dalam kategori nomina. Fungsi predikat $(\mathrm{P})$ diisi oleh kata kini melanjutkan yang menempati peran sebagai tindakan dan termasuk dalam kategori verba. Kata karier memiliki fungsi pelengkap (Pel) yang memiliki peran sebagai sasaran dan termasuk dalam kategori nomina. Adapula kata sebagai promotor tinju di bawah naungan Golden Boy Promotion memiliki fungsi keterangan (Ket.) yang termasuk dalam kategori frasa adverbial.

\section{SIMPULAN}

Berdasarkan hasil analisis pola kalimat dalam rubrik olahraga surat kabar online Kompas.com edisi Maret 2021, dapat disimpulkan bahwa: pertama, ditemukan beberapa bentuk pola kalimat tunggal yang berpola SPO, SPK, SPOK, dan SPPelK. Adapula beberapa bentuk pola kalimat majemuk yang ditemukan, yaitu SPOPOK, SPOPO, SPSKPO, dan KSPPel. Menurut hasil analisis pola kalimat berdasarkan: (1) Fungsi dapat ditemukan: (a) fungsi subjek (S) termasuk dalam kategori nomina atau pronominal, (b) fungsi predikat (P) termasuk dalam kategori verba aktif atau pasif, (c) fungsi objek $(\mathrm{O})$ termasuk dalam kategori nomina, (d) fungsi pelengkap (Pel) termasuk dalam kategori nomina, dan (e) fungsi keterangan (Ket) termasuk dalam kategori adverbial atau pun adjektiva; Berdasarkan peran sintaksis dapat ditemukan: (a) fungsi subjek (S) menempati peran sebagai pelaku, (b) fungsi predikat $(\mathrm{P})$ menempati peran sebagai tindakan, (c) fungsi objek $(\mathrm{O})$ menempati peran sebagai penerima dan tujuan, (d) fungsi pelengkap (Pel) menempati peran sebagai penderita, dan (e) fungsi keterangan (Ket) menempati peran sebagai keterangan asal, tujuan, dan sifat. Kalimat dalam rubrik olahraga pada kompas.com cenderung menggunakan kalimat majemuk, di mana banyak terdapat perluasan fungsi sintaksis pada beberapa data. Selain itu, terdapat juga kesalahan dalam penempatan fungsi kalimat pada beberapa data, sehingga kalimat yang dihasilkan tidak padu dan tidak sesuai dengan kaidah sintaksis Bahasa Indonesia.

\section{DAFTAR PUSTAKA}

Adnyana. I. K. S; Suwendi. M; Dayu Novita Yogan Dewi. (2018). "Dominasi Laki-laki pada Masyarakat Matrilineal Suku Tetun, Kabupaten Malaka, Nusa Tenggara Timur Berdasarpada Penggunaan Bahasa". Prosiding Seminar Nasional Menggali Pengalaman Pembelajaran Bahasa dan Sastra 
Indonesia di Sekolah. Program Studi Pendidikan Bahasa dan

Sastra Indonesia. Universitas Pendidikan Ganesha. Singaraja 2021September 2018. Halaman 4050.

Aditia, R., \& Utomo, A. P. Y. (2021).

Analisis klausa yang menduduki fungsi predikat pada berita "pertumbuhan ekonomi kuartal IV diprediksi masih minus, daya beli masyarakat kian buruk." Widya Accarya: Jurnal Kajian Pendidikan FKIP Universitas Dwijendra, 12(1), 7-17. https://doi.org/https://doi.org/10.46650 /wa.12.1.1022.7-17

Arifin, Z. (2008). Sintaksis. PT Grasindo. Ariyadi, A. D., \& Utomo, A. P. Y. (2020). Analisis Kesalahan Sintaksis pada Teks Berita Daring berjudul Mencari Etika Elite Politik di saat Covid-19. Jurnal Bahasa Dan Sastra, 8(3), 138145.

Dewi, W. W. R. (2009). Sintaksis Bahasa Indonesia. Intan Pariwara.

Faraba, K. S. A., Setyaningrum, N., \& Sumarlam, S. (2017). Pelesapan subjek dan predikat pada judul-judul berita Line News populer. Jurnal Pena Indonesia, 3(1), 42-58.

Goziyah, G., \& Insani, H. R. (2018). Kohesi dan koherensi dalam koran bisnis Indonesia dengan judul kemenperin jamin serap garam rakyat. Silampari Bisa: Jurnal Penelitian Pendidikan Bahasa Indonesia, Daerah, Dan Asing, 1(1), 138-153.

Haryanti, E., Lestari, A. D., \& Sobari, T. (2018). Pemerolehan bahasa anak usia 2-3 tahun ditinjau dari aspek fonologi|. Parole (Jurnal Pendidikan Bahasa Dan Sastra Indonesia), 1(4), 591-602.

Haryati, T., Baskora, R., Putra, A., \& Setyawati, H. (2017). Analisis isi pemberitaan olahraga pada rubrik gelora harian wawasan. Jurnal PENJAKORA, 4(2), 36-45.

Hermawan, A. (2018). Makna judul berita olahraga basket ball harian Kompas bulan Maret 2018 dalam kajian semantik. BRILIANT: Jurnal Riset Dan Konseptual, 3(3), 330-337.

Kridalaksana, H. (2008). Kamus Linguistik. Gramedia Pustaka Utama.

Liusti, S. A. (2016). Analisis kalimat berdasarkan pola kalimat dasar dan kalkulus predikat. Adabiyyāt: Jurnal Bahasa Dan Sastra, 15(2), 157-175.

Mayasari, D. (2017). Fungsi dan peran sintaksis bahasa Indonesia dalam rubrik deteksi harian Jawa Pos. Sastranesia, 5(3), 1-9.

Mayasari, D., \& Ardhana, N. R. (2018). Publikasi bentuk fungsi dan kategori sintaksis tuturan masyarakat manduro sebagai pendukung perkembangan bahasa anak usia dini. Jurnal Obsesi : Jurnal Pendidikan Anak Usia Dini, 2(1), 54-63.

Mughofiroh, I., Mulyaningsih, I., \& Itaristanti, I. (2019). Analisis gaya bahasa dalam berita olahraga Kabar Cirebon. BAHASA: Jurnal Keilmuan Pendidikan Bahasa Dan Sastra Indonesia, 1(3), 159-172.

Munariswati, M., Sumarlam, S., \& Subroto, E. (2017). Pola urutan fungsi keterangan berdasarkan hubungannya dengan predikat verba dalam kalimat tunggal deklaratif bahasa Indonesia. Prasarti: Journal of Linguistics, 2(2), 284-299.

Nirmalasari, Y. (2018). Pola kalimat bahasa Indonesia tulis pembelajar BIPA tingkat pemula asal Tiongkok di Universitas Ma Chung tahun 2018. KLAUSA (Kajian Linguistik, Pembelajaran Bahasa, Dan Sastra), 2(1), 41-50. https://doi.org/10.33479/klausa.v2i01.1 42

Nisa, K. (2018). Analisis kesalahan berbahasa tiga berita pilihan pada surat kabar Sinar Indonesia Baru edisi November 2017. Jurnal Komunitas Bahasa, 6(1), 54-61. https://doi.org/10.32502/jbs.v2i2.1261

Rejeki, A. S. (2015). Analisis Kalimat dalam Teks Narasi Mahasiswa Program Alih Kredit Yunnan University of 
Nationality di Universitas Negeri

Yogyakarta. Universitas Negeri

Yogyakarta.

Rinanda, Z. A. (2012). Analisis Struktur

Kalimat pada Waca Iklan Brosur

Provider Telekomunikasi. Universitas

Negeri Yogyakarta.

Santika, I. G. N. (2017). Kepala Sekolah

Dalam Konsep Kepemimpinan

Pendidikan: Suatu Kajian Teoritis.

Widya Accarya, 7(1).

Santika, I. G. N. (2018). Strategi

Meningkatkan Kualitas SDM

Masyarakat Desa Padangsambian Kaja

Melalui Pendidikan Karakter

Berbasiskan Kepedulian Lingkungan

Untuk Membebaskannya Dari Bencana

Banjir. Widya Accarya, 9(1).

Santika, I. G. N. (2021). Grand Desain

Kebijakan Strategis Pemerintah Dalam

Bidang Pendidikan Untuk Menghadapi

Revolusi Industri 4.0. Jurnal

Education and Development, 9(2), 369-377.

Septianingtias, V. (2015). Pola kalimat pada kumpulan dongeng gadis korek api karya H.C. Andersen (suatu kajian sintaksis). Jurnal Pesona, 1(1), 42-49.

Sudaryanto, S. (2015). Metode dan Aneka

Teknik Analisis Bahasa (Pengantar

Penelitian Wahana Kebudayaan

Secara Linguistis). Sanata Dharma

University Press.

Surbakti, E. B. (2012). Tipologi sintaksis bahasa karo. Telangkai Bahasa Dan Sastra, 6(1), 55-73.

Suwarto, S. (2016). Analisis Pola Kalimat Bahasa Indonesia dalam Karangan Siswa Kelas VI SD Negeri 02 Nglegok. Universitas Muhammadiyah Surakarta.
Swarniti, N. W. (2021). A Corpus Based Approach to the Analysis of Structures in Prepositional Phrase. Yavana Bhasha: Journal of English Language Education, 4(1), 18-22.

https://doi.org/http://dx.doi.org/10.250 78/yb.v4i1.2207

Tarigan, H. G. (2009). Pengajaran Sintaksis. ANGKASA.

Tarmini, W., \& Sulistyawati, S. (2019). Sintaksis Bahasa Indonesia (1st ed.). UHAMKA Press.

Utomo, A. P. Y., Haryadi, H., Fahmy, Z., \& Indramayu, A. (2019). Kesalahan bahasa pada manuskrip artikel mahasiswa di Jurnal Sastra Indonesia. Jurnal Sastra Indonesia, 8(3), 234241.

Verhaar, J. (2001). Asas-Asas Linguistik Umum (3rd ed.). Gadjah Mada University Press.

Wahyuni, R. T., Darmuki, A., \& Hasanudin, C. (2019). Analisis pola, fungsi, kategori, dan peran sintaksis pada kalimat tunggal dalam surat kabar harian Kompas. Jurnal Bahtera, 6(12), 659-670. https://doi.org/https://doi.org/10.37729 /btr.v6i12.6024

Widiatmoko, W. (2015). Analisis kohesi dan koherensi wacana berita rubrik nasional di majalah online detik. Jurnal Sastra Indonesia, 4(1), 1-12.

Yunregiarsih, L. G., Tarmini, W., \& Mustofa, A. (2014). Pola sintaksis pada poster dan implikasi dalam pembelajaran bahasa indonesia di SMP. Jurnal Kata (Bahasa Sastra Dan Pembelajaran), 2(3), 1-12. 